\title{
Overexpression of an apple LysM- containing protein gene, MdCERK1-2, confers improved resistance to the pathogenic fungus, Alternaria alternata, in Nicotiana benthamiana
}

Qiming Chen ${ }^{1,2,3+}$, Chaohua Dong ${ }^{1,2,3+}$, Xiaohong Sun ${ }^{1,2}$, Yugang Zhang ${ }^{2,4}$, Hongyi Dai ${ }^{2,4}$ and Suhua Bai ${ }^{1,2,3^{*}}$

\begin{abstract}
Background: Lysin motif (LysM)-containing proteins are involved in the recognition of fungal and bacterial pathogens. However, few studies have reported on their roles in the defense responses of woody plants against pathogens. A previous study reported that the apple MdCERK1 gene was induced by chitin and Rhizoctonia solani, and its protein can bind to chitin. However, its effect on defense responses has not been investigated.

Results: In this study, a new apple CERK gene, designated as MdCERK1-2, was identified. It encodes a protein that shares high sequence identity with the previously reported MdCERK1 and AtCERK1. Its chitin binding ability and subcellular location are similar to MdCERK1 and AtCERK1, suggesting that MdCERK1-2 may play a role in apple immune defense responses as a pattern recognition receptor (PRR). MdCERK1-2 expression in apple was induced by 2 fungal pathogens, Botryosphaeria dothidea and Glomerella cingulate, but not by the bacterial pathogen, Erwinia amylovora, indicating that MdCERK1-2 is involved in apple anti-fungal defense responses. Further functional analysis by heterologous overexpression (OE) in Nicotiana benthamiana ( $\mathrm{Nb}$ ) demonstrated that MdCERK1-2 OE improved $\mathrm{Nb}$ resistance to the pathogenic fungus, Alternaria alternata. $\mathrm{H}_{2} \mathrm{O}_{2}$ accumulation and callose deposition increased after A. alternata infection in MdCERK1-2 OE plants compared to wild type (WT) and empty vector (EV)-transformed plants. The induced expression of NbPAL4 by A. alternata significantly $(p<0.01, n=4)$ increased in MdCERK1-2 OE plants. Other tested genes, including NbNPR1, NbPR1a, NbERF1, and NbLOX1, did not exhibit significant changes after A. alternata infection in OE plants compared to EV or WT plants. OE plants also accumulated more polyphenols after A. alternata infection.

(Continued on next page)
\end{abstract}

\footnotetext{
* Correspondence: shbai0402@126.com

${ }^{\dagger}$ Qiming Chen and Chaohua Dong contributed equally to this work.

${ }^{1}$ College of Life Sciences, Key Laboratory of Plant Biotechnology of

Shandong Province, Qingdao Agricultural University, 700 Changcheng Road,

Qingdao 266109, China

${ }^{2}$ Qingdao Key Laboratory of Genetic Improvement and Breeding in

Horticultural Plants, Qingdao Agricultural University, Qingdao 266109, China

Full list of author information is available at the end of the article
}

(C) The Author(s). 2020 Open Access This article is licensed under a Creative Commons Attribution 4.0 International License, which permits use, sharing, adaptation, distribution and reproduction in any medium or format, as long as you give appropriate credit to the original author(s) and the source, provide a link to the Creative Commons licence, and indicate if changes were made. The images or other third party material in this article are included in the article's Creative Commons licence, unless indicated otherwise in a credit line to the material. If material is not included in the article's Creative Commons licence and your intended use is not permitted by statutory regulation or exceeds the permitted use, you will need to obtain permission directly from the copyright holder. To view a copy of this licence, visit http://creativecommons.org/licenses/by/4.0/ The Creative Commons Public Domain Dedication waiver (http://creativecommons.org/publicdomain/zero/1.0/) applies to the data made available in this article, unless otherwise stated in a credit line to the data. 
(Continued from previous page)

Conclusions: Heterologous MdCERK1-2 OE affects multiple defense responses in Nb plants and increased their resistance to fungal pathogens. This result also suggests that $M d C E R K 1-2$ is involved in apple defense responses against pathogenic fungi.

Keywords: Fungal pathogen, LysM-containing protein, Malus $\times$ domestica, Nicotiana benthamiana, Plant immunity

\section{Background}

Plants are constantly subjected to attack from various pathogenic microorganisms. To fight against pathogen infection, plants have developed sophisticated immune systems that ward off pathogens and protect the plant from infection. During pathogen infection, plants first detect pathogen-associated molecular patterns (PAMPs) via pattern recognition receptors (PRRs), and then initiate a series of rapid PAMP-triggered immunity (PTI) responses to limit the proliferation and spread of pathogens [1]. Thus, PRRs are a pivotal component of innate plant immune systems. To date, some plant PRRs have been identified [2], including FLAGELLIN SENSING 2 (FLS2) [3], LYM1/3 [4], ELONGATION FACTOR-TU RECEPTOR (EFR) [5], PEP1 RECEPTOR 1 (PEPR1), PEPR2 [6-8], CHITIN ELICITOR RECEPTOR KINASE1 (CERK1) [9-11], and CHITIN ELICITOR BINDING PROTEIN (CEBiP) [12], which perceive the flg22 bacterial flagellin epitope, bacterial peptidoglycan, EF-Tu epitope elf18, plant elicitor peptides (Peps) released during pathogen infection, and chitin, respectively. Upon binding to corresponding ligands, these PRRs initiate downstream defense responses, such as a transient influx of calcium ions, ROS bursts, MAPKs activation, and the increased expression of pathogenesis-related (PR) protein genes.

Lysin motif (LysM)-containing proteins are involved in the recognition of fungal and bacterial pathogens as PRRs. They were first identified from bacteria with the ability to bind to peptidoglycan (PGN) [13]. OsCEBiP and AtCERK1 are well-studied plant LysM-containing proteins that recognize chitin, a representative PAMP of pathogenic fungi that initiates downstream immune responses [14]. AtCERK1 contains a 3-LysM ectodomain and intracellular Ser/Thr kinase region, and is an essential receptor for chitin elicitor signaling in Arabidopsis thaliana [9]. Two AtCERK1s form a sandwich-type heterotetramer complex with a LysM-containing receptorlike kinase (LYK), LYK5, another LysM-containing protein with higher chitin binding affinity that is indispensable for chitin-induced AtCERK1 phosphorylation and immune responses in Arabidopsis [15]. Rice CERK1 (OsCERK1) contains 2 LysMs, a transmembrane region, and an intracellular Ser/Thr kinase region that is essential for the transduction of immune signals [16]. Unlike AtCERK1, OsCERK1 does not directly bind to chitin. Instead, it recognizes chitin by forming a sandwich-like heterotetramer complex receptor with OsCEBiP, another LysM-containing protein with the ability to bind to chitin that elicits downstream immune responses in rice $[12,17]$. OsCEBiP lacks an intracellular kinase domain and depends on OsCERK1 to transmit signals to plant cells.

In addition to the aforementioned LysM proteins, many other members of this family are involved in pathogen recognition. The Arabidopsis genome encodes 5 LYKs: LYK1/ CERK1 and LYK2 through 5 [11, 18]. LYK3 is involved in chitin signaling as a negative regulator in the regulation of Arabidopsis resistance to Botrytis cinerea and Pectobacterium carotovorum infection. Its expression was strongly repressed by elicitors (OGs and flg22) and fungal infection, and induced by the hormone, abscisic acid (ABA) [19]. LYK4 binds to chitin or chitooctaose, and the binding was partially repressed in a $l y k 4$ mutant [20]. LYK5 recognizes long-chain chitooligosaccharides and forms a complex with CERK1. This complex activates the CERK1 kinase domain and induces downstream immune responses [21]. LysMcontaining glycosylphosphatidylinositol-anchored protein 2 (LYM2) is an OsCEBiP homologue in Arabidopsis, but the lym2 mutant did not affect CERK1-mediated chitin responses. Instead, LYM2 participated in the CERK1independent pathway by mediating a reduction in molecular flux in the presence of chitin [22], as well as contributed to disease resistance against $A$. brassicicola through the perception of chitin [23]. Interestingly, LYK proteins in legumes are essential receptors for the perception of lipochitooligosaccharide nodulation factors (NFs) produced by rhizobia and are essential for the establishment of nitrogenfixing symbiosis [24-29].

Functional analysis of LysM-containing proteins demonstrated the importance of the LysM domain in fungal pathogen recognition. Although in-depth investigations have been performed in rice and Arabidopsis, limited information has been reported on LysM-containing proteins in apple or other woody plants. Thus, it remains unclear whether apple utilizes the same mechanism as Arabidopsis or rice to recognize fungal pathogens and trigger downstream defense responses. Recently, Zhou et al. [30] reported an apple CERK1 like protein, MdCERK1, which was induced by chitin and Rhizoctonia solani. These findings provided evidences that MdCERK1 may also play a role in apple defense responses against fungal pathogens. In this study, a gene encoding the LysM-domain containing protein was identified in apple tissues infected with Botryosphaeria dothidea. The 
corresponding protein shared highly similarity with MdCERK1 (designated as MdCERK1-2). Results revealed that MdCERK1-2 overexpression (OE) in Nicotiana benthamiana $(\mathrm{Nb})$ plants improved their resistance to fungal pathogens.

\section{Results}

Characterization of a LysM-containing protein kinase from Malus $\times$ domestica

A gene (GDR ID: MD17G1102100) encoding LysMcontaining protein kinase was found to be highly expressed in shoot barks of apple by $B$. dothidea as revealed by transcriptome approach. Its protein contains a long extracellular region, a transmembrane domain and an intracellular Ser/Thr kinase domain, and was highly homologous to chitin recognition proteins MdCERK1 [30] and AtCERK1 [9, 10]. Furthermore, the motif analysis revealed that the extracellular region consists of a signal peptide consisting of 21 amino acids and 3 LysMs (Figs. 1a; S1). The domain composition of the newly identified protein was similar to MdCERK1. To distinguish it from MdCERK1, the newly identified gene was designated as MdCERK1-2. Homologous alignment revealed that the MdCERK1-2 protein shared high sequence identity with MdCERK1 (82.9\%), OsCERK1 (57.6\%), and AtCERK1 (57.1\%) (Fig. S2). By aligning MdCERK1-2 with well-studied LysM-containing proteins, 7 residues that are crucial for NAG binding were found in LysM2, which are similar to the other reported LysM-containing proteins $[14,31]$ (Fig. 1b), suggesting that MdCERK1-2 can bind to NAG. The phylogenetic analysis revealed that MdCERK1-2 was closely related to MdCE RK1, OsCERK1, AtCERK1, and AtLYK3 (Fig. 1c). According to early reports, these proteins are all involved in the defense against fungal pathogens $[9,19,30]$, suggesting that MdCERK1-2 may also be involved in the defense responses against fungal pathogen infection.

\section{MdCERK1-2 exhibited similar subcellular location and chitin-binding activity as MdCERK1 and AtCERK1}

Subcellular location revealed that MdCERK1-2 was located at the plasma membrane. Fluorescence of the MdCERK12-GFP fusion protein was detected at the plasma membrane (Fig. 2a). This result was confirmed by subsequent immunobloting experiments using an anti-GFP antibody. Abundant MdCERK1-2-GFP proteins existed in the microsomal fraction. No detectable MdCERK1-2-GFP was observed in the soluble fraction (Fig. 2b). Binding assays using recombinant proteins demonstrated that the putative ectodomain of MdCERK1-2 specifically bound to chitin, but did not bind to PGN (Fig. 2c). In contrast, under the same conditions, obvious binding to PGN was observed in AtLYM1, a plasma membrane protein of Arabidopsis that physically interacts with PGNs and mediates Arabidopsis sensitivity to PGNs in gram-negative and gram-positive bacteria [4].

\section{MdCERK1-2 expression increased during $B$. dothidea infection}

To examine the expression changes in response to $B$. dothidea infection, the expressions of MdCERK1-2 and other 4 apple $L Y K$ genes were analyzed, including $M d C E R K 1$ and 3 putative $L Y K$ genes, MdLYK3, MdLYK4, and MdLYK5 (Table S1). In apple shoot bark and fruits, two target tissues of $B$. dothidea infection, only $M d C E R K 1-2$ was significantly $(p<0.01, n=4)$ upregulated after $B$. dothidea infection compared to the mock-infected control (Fig. 3a, b). No significant changes were observed in the expressions of other LYK genes, including MdCERK1 (Fig. 3a, c-f). Next, whether MdCERK1-2 could be induced by other apple fungal and bacterial pathogens was examined. MdCERK1-2 expression also increased in the young leaves of apple plantlets after inoculation with the apple fungal pathogen, Glomerella cingulate (Fig. 3g). However, no significant expression changes of MdCERK1-2 were observed after Erwinia amylovora infection, a bacterial pathogen (Fig. 3h). These results suggest that $M d C E R K 1-2$ was involved in the immune defense responses against fungal pathogens.

\section{MdCERK1-2 OE improved the resistance of $\mathrm{Nb}$ plants to $A$. alternata}

To generate $\mathrm{OE}$ transgenic $N b$ plants, binary vectors carrying $M d C E R K 1-2$ and the $3 \mathrm{HA}$ tags were introduced into $\mathrm{Nb}$ using Agrobacterium-mediated transformation. Transgenic lines were screened using hygromycin and carbeniclllin. All of the obtained transgenic lines were confirmed by PCR with genomic DNA as template (Fig. 4a). The expression of $M d C E R K 1-2$ was confirmed using immunobloting. The identified transgenic lines exhibited high levels of MdCERK1-2 expression (Fig. 4b). No visible difference in phenotype was observed between transgenic and wild-type (WT) plants. Next, whether $M d C E R K 1-2 \mathrm{OE}$ altered the resistance of $\mathrm{Nb}$ plants to pathogenic fungi was tested. MdCERK1-2 OE plants were used for $A$. alternata inoculation. EV-transformed $\mathrm{Nb}$ and WT plants were used as the controls. No obvious lesions were observed 5 days post-inoculation (dpi). Visible lesions were observed at $8 \mathrm{dpi}$ on almost all OE, $\mathrm{EV}$, and WT plants. However, there were significantly $(p<0.01, n=5)$ milder lesions on OE plants compared to EV and WT plants. Only small lesions were observed on OE plants, while more severe lesions were observed on EV and WT plants (Fig. 4c, d). Fungal growth was also evaluated by microscopic observation and relative fungal mass was calculated. Hypha growth was observed at 3 and $5 \mathrm{dpi}$, although no visible lesions were observed. At $8 \mathrm{dpi}$, heavy hyphae growth was observed in WT and $\mathrm{EV}$ plants, while the relative fungal mass of $\mathrm{OE}$ plants 
(a)

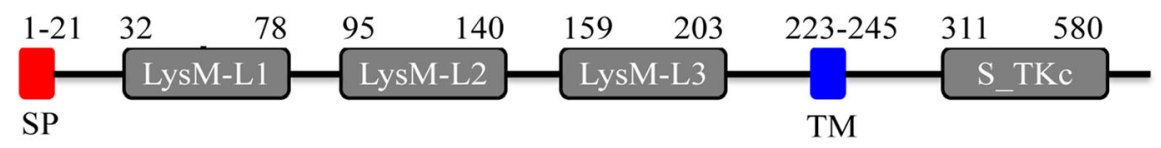

(b)

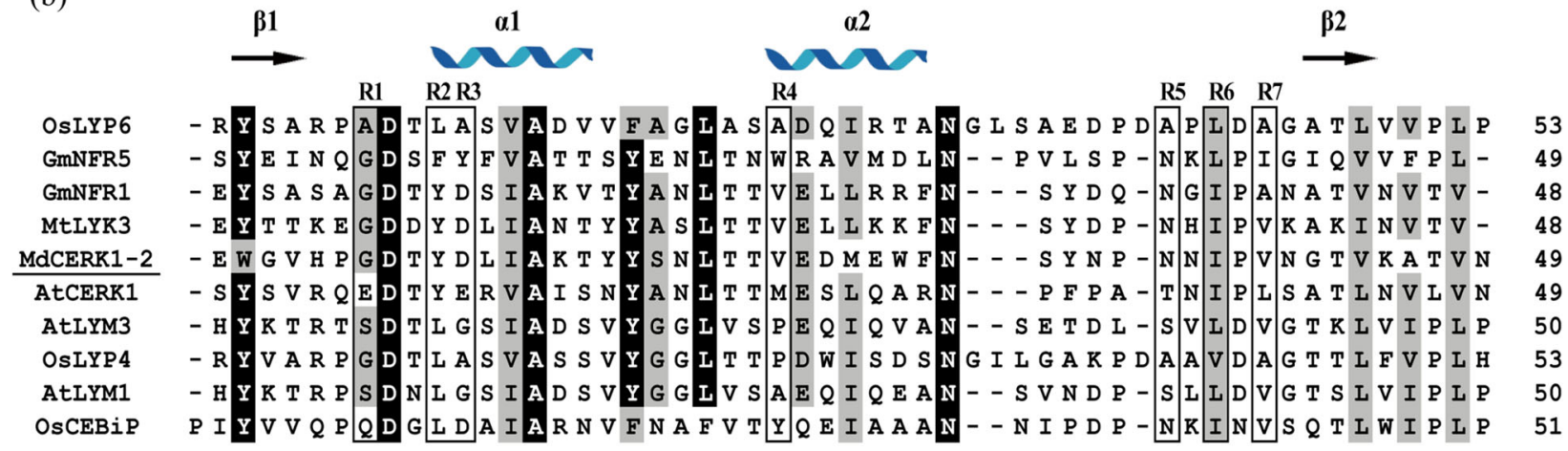

(c)

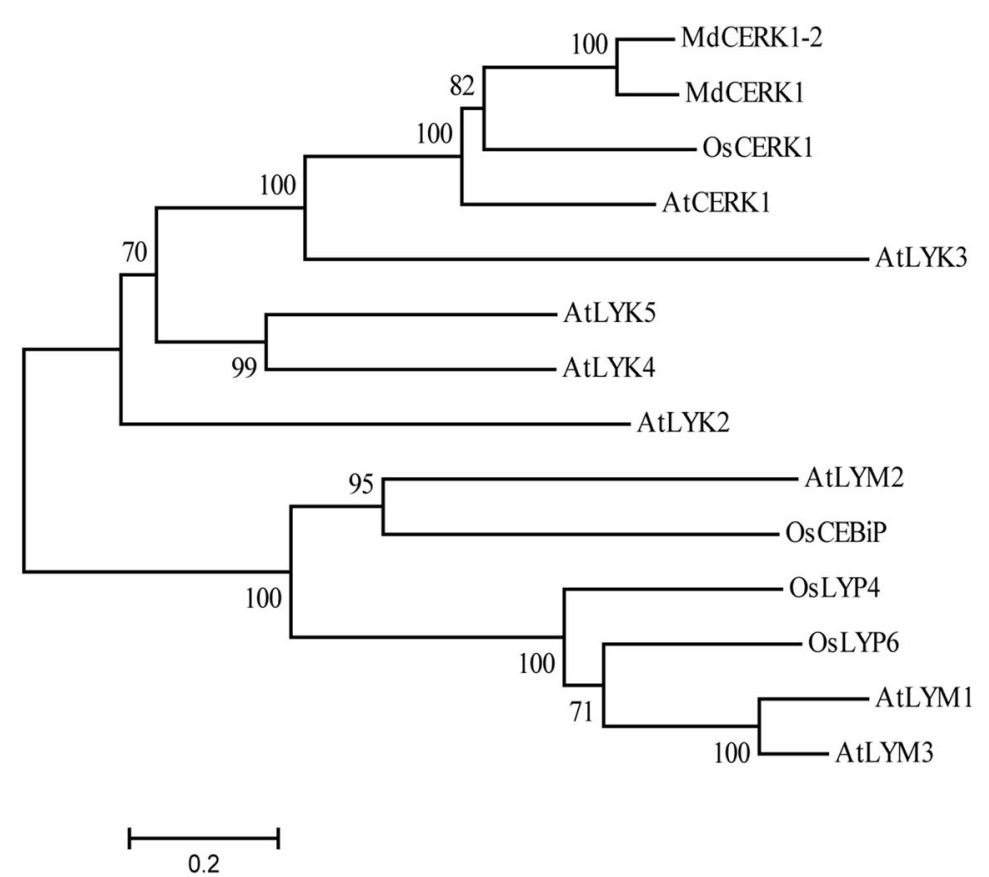

Fig. 1 Characterization of the MdCERK1-2 protein. a Motifs and domains of the MdCERK1-2 protein. Numbers indicate the position of amino acids. SP, signal peptide; TM, transmembrane region. b Sequence alignment of LysM proteins. Consensus and similar amino acid residues for all sequences are highlighted with black or gray background. R1-R7 indicate 7 crucial positions of NAG recognition. R4, R6 and R7 are hydrophobic amino acid residues. c Phylogenetic tree of LYK proteins from apple, rice and Arabidopsis. The tree was constructed in MEGA 5.0 using the neighbor-joining $(\mathrm{NJ})$ method. Bootstrap support values are indicated with numbers at the nodes. Proteins used in the phylogenetic tree are summarized in Table S1

was significantly $(p<0.01, n=5)$ lower compared to WT and EV plants (Fig. $5 \mathrm{a}, \mathrm{b}$ ).

ROS accumulation and callose deposition increased in MdCERK1-2 OE plants

To further examine the effects of MdCERK1-2 on defense responses, ROS accumulation and callose deposition were evaluated using $\mathrm{DAB}$ and aniline blue staining, respectively. Significant $(p<0.01 ; \mathrm{n}=5)$ increases in ROS accumulation were detected in OE plants compared to EV plants at $72 \mathrm{~h}$ post-inoculation (hpi) with A. alternata (Fig. 6a). Xylenol orange assays were used to quantify ROS accumulation and confirmed the enhanced ROS levels in OE plants (Fig. 6c). No significant differences were observed among OE, 
(a)

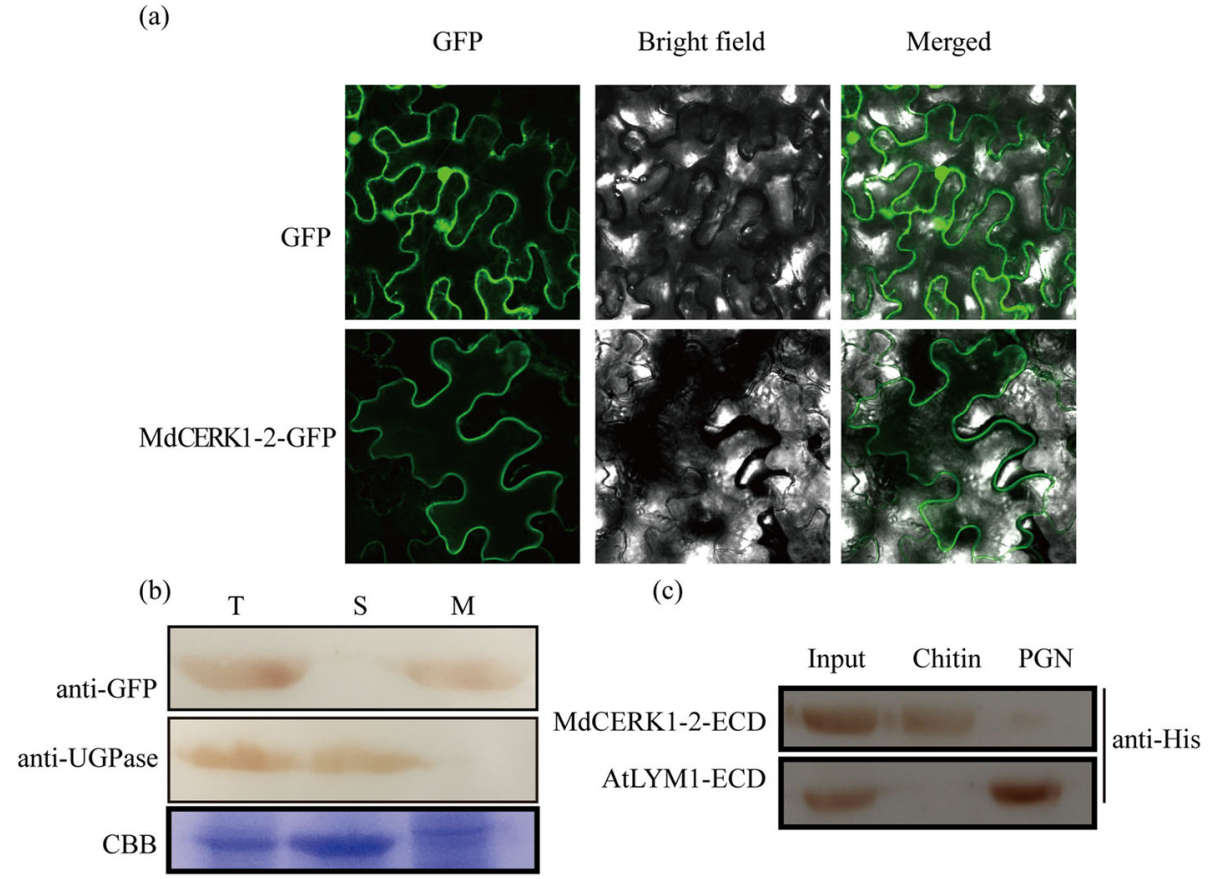

Fig. 2 Subcellular localization and ligand binding of the MdCERK1-2 protein. a Subcellular localization of MdCERK1-2. The MdCERK1-2-GFP fusion gene was transiently expressed in Nb leaves using the A. tumefaciens-mediated method and observed with a confocal microscope (bottom). The control expressing GFP was also observed (top). b Membrane proteins from Nb plants expressing MdCERK1-2-GFP were prepared and separated with SDS-PAGE. The presence of MdCERK1-2-GFP in membrane proteins was determined by immunobloting with an anti-GFP antibody. S, soluble protein; T, total protein; M, membrane protein; CBB, Coomassie brilliant blue staining. Anti-UGPase was used as internal reference of cytoplasm protein. c MdCERK1-2-ECD binds to chitin, but does not bind to PGN. Binding proteins were separated by SDS-PAGE and detected by immunobloting with an anti-His antibody

EV, and WT plants under mock-infection conditions. Chitin treatment also induced significantly $(p<0.01 ; n=7)$ higher $\mathrm{H}_{2} \mathrm{O}_{2}$ generation in OE plants compared to WT and EV plants (Fig. 6e). Callose deposition was visualized by aniline blue staining and quantified by digital count measurements. MdCERK1-2 OE significantly $(p<0.01 ; n=$ 9) increased callose deposition in OE plants compared to EV and WT plants (Fig. 6b, d). These results suggest that MdCERK1-2 OE positively regulates ROS accumulation and callose deposition in response to A. alternata infection.

\section{MdCERK1-2 OE affects the expression of defense-related genes}

To determine whether MdCERK1-2 OE affects the expression of defense-related genes during pathogen infection, defense-related genes were quantified by qRT-PCR at different time points after A. alternata inoculation (Fig. 7), including the salicylic acid (SA)-related genes, NbNPR1 and NbPR1a [32, 33], jasmonic acid (JA)-responsive gene, NbLOX1 [32, 33], ethylene-responsive gene, NbERF1 [32], and NbPAL4, a gene involved in the biosynthesis of polyphenol compounds [34, 35]. The basal expression of these genes did not show significant differences among OE, EV, and WT plants (Fig. 7a). After A. alternate infection, $N b P A L 4$ exhibited significantly $(p<$
$0.01, n=4)$ higher expression in OE plants compared to EV and WT plants (Fig. 7f). In contrast, NbNPR1, NbPR1a, NbERF1, and NbLOX1 were not significantly different between OE and WT plants, although these genes were induced by $A$. alternata infection.

\section{MdCERK1-2 OE alters polyphenolic metabolism in $\mathrm{Nb}$ plants}

The differences in NbPAL4 gene expression between OE and WT plants suggest that polyphenolic metabolism and the SA signaling pathway may be influenced by MdCERK1-2 OE. Total phenolic contents and SA levels were analyzed to determine the effects of MdCERK1-2 OE. After A. alternata infection, all of the tested plants exhibited significantly enhanced polyphenol content levels $(p<0.05 ; \mathrm{n}=4)$. Polyphenol contents in OE plants were clearly higher than that in EV and WT plants (Fig. 8a). In contrast, SA levels were not significantly different (Fig. 8b, c). MdCERK1-2 OE did not alter basal SA levels (Fig. 8b). Although the SA levels of all of the tested plants increased after $A$. alternata infection, MdCERK1-2 OE did not result in significant differences in SA levels between $\mathrm{OE}$ and WT plants or between OE and EV plants in response to A. alternata infection (Fig. 8c). 


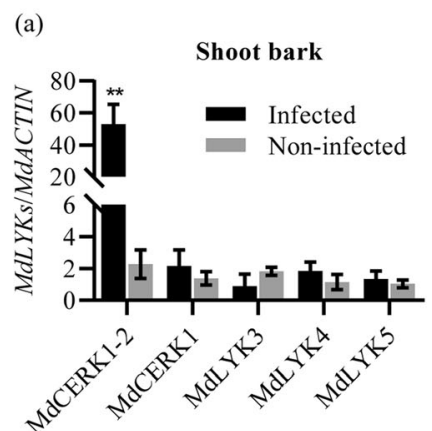

(d)

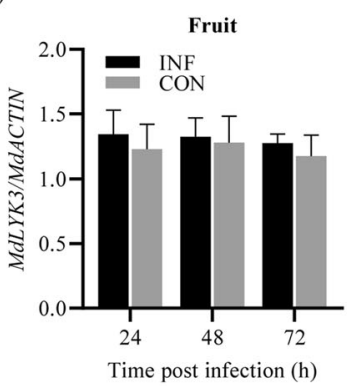

(g)

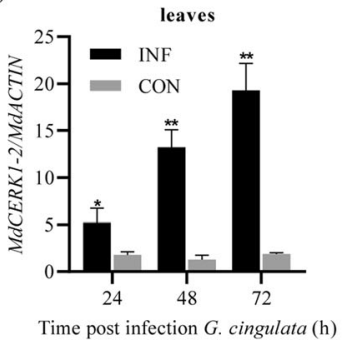

(b)

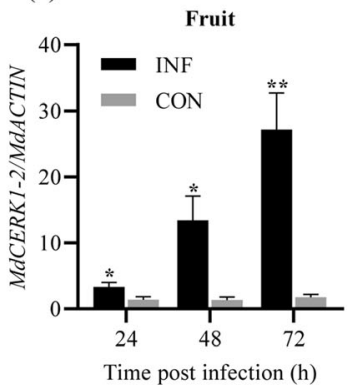

(e)

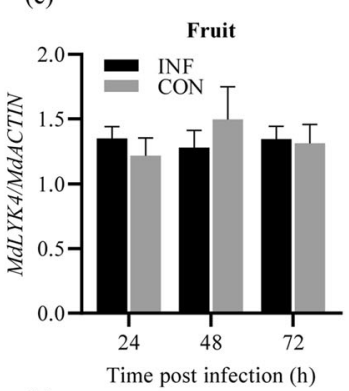

(h)

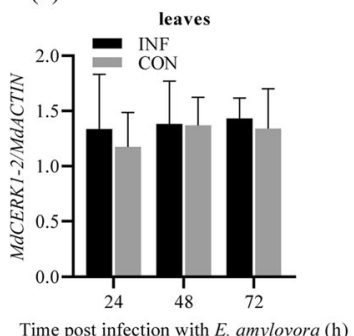

(c)

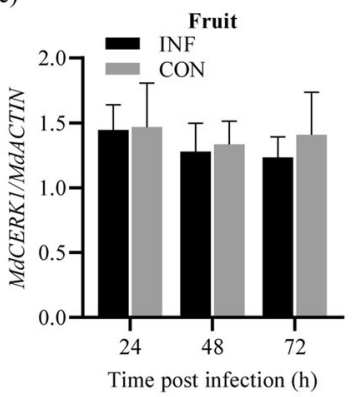

(f)

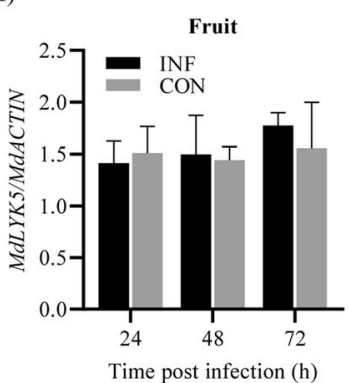

Fig. 3 Expression of apple MdLYKs. a MdLYKs expression in shoot bark was induced by B. dothidea. Samples were collected 28 dpi when warts were just visible. b-f MdLYKs expression in fruits induced by B. dothidea. $\mathbf{g}, \mathbf{h}$ MdCERK1-2 expression in leaves inoculated with E. amylovora or G. cingulata. INF: infected sample; CON: mock infected sample. Four replicates were used for each experiment and experiments were performed at least 3 times. The data are presented as the mean \pm SD $(n=4)$ and were subjected to a two-way ANOVA followed by Tukey's post-hoc test. Significant differences were determined when $p<0.05$. Asterisks indicate significant differences when compared to the control (** $p<0.01$ )

\section{Discussion}

Both AtCERK1 and OsCERK1 are required for chitin signaling and plant resistance to fungal pathogens $[9,10$, $12,17,31,36]$, but their recognition mechanisms for chitin differ. It is important to determine whether the apple CERK1 homologue plays an important role in fungal pathogen defense. Data presented here indicate that the apple MdCERK1-2 gene is also involved in the defense against fungal pathogens. Specifically, MdCERK1-2 OE improved the resistance of $\mathrm{Nb}$ plants to A. alternata and affected their immune response. This work, combined with the findings reported by Zhou et al. [30], confirmed that apple CERK1 also functions as a PRR, recognizing fungal pathogen and playing an important role in apple plant defense against fungal pathogens.

The gene expression data indicate that MdCERK1-2 was induced by 2 fungal pathogens, B. dothidea and $G$. cingulate, but not by the bacterial pathogen, E. amylovora, suggesting that its expression changes were not specifically in response to $B$. dothidea. Generally, PRRs recognize conserved microbial molecules, but not certain specific pathogens. The expression changes of $M d C E R K 1-2$ in response to different pathogenic fungi may reflect a broadspectrum property of MdCERK1-2 as a potential PRR. MdCERK1-2 expression was not induced by E. amylovora in apple, but this was not enough to exclude its involvement in the defense against bacterial pathogens. MdCERK1-2 may not function as a PRR in the defense against bacterial pathogens just as AtCERK1 or OsCERK1. The two proteins are required for bacteria recognition via interacting with LYM1 and LYM3 in Arabidopsis, or OsLYP4 and OsLYP6 in rice, which physically interact with PGN [4, 37], a bacterial PAMP.

The enhanced expression of MdCERK1-2 after pathogenic fungi infection suggests that high MdCERK1-2 levels are required for it to function as PRR. It is known 
(a)

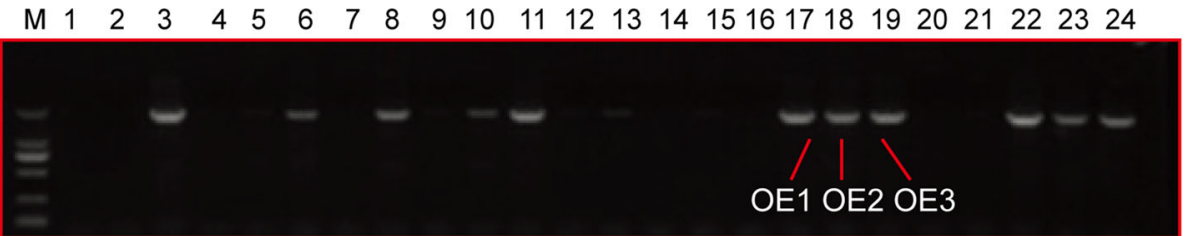

(b)

(d)

(c)
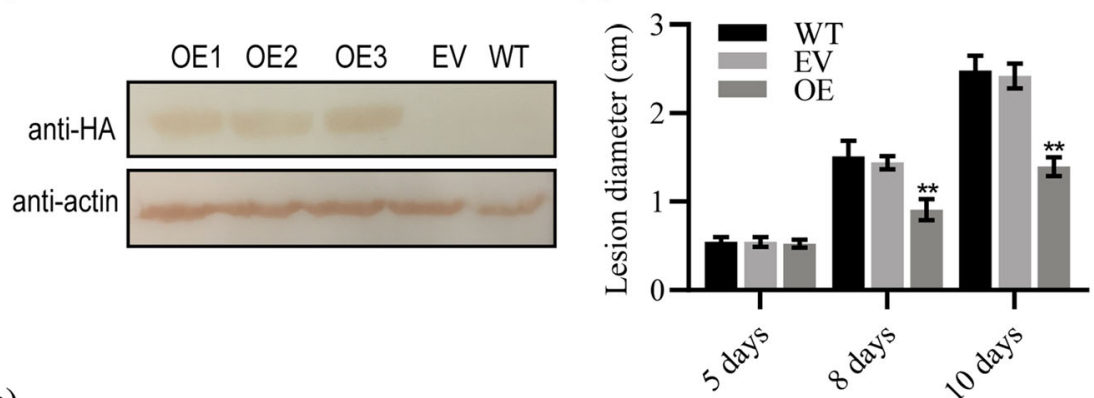

Time post infection

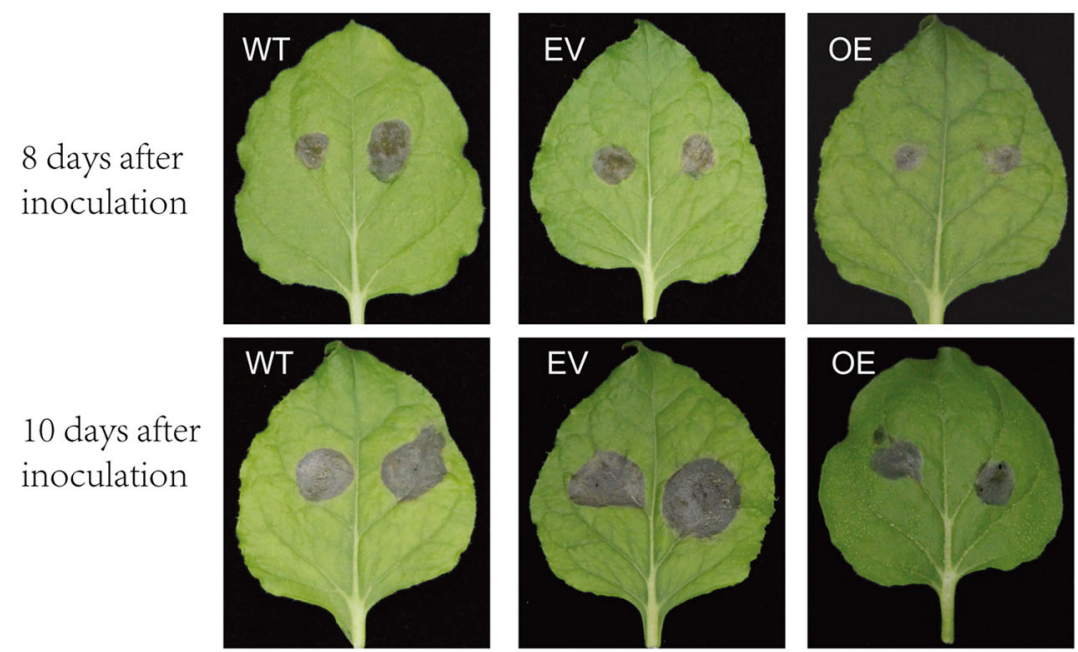

Fig. 4 MdCERK1-2 OE improved the resistance of Nb plants to A. alternata. a Transgenic plants were screened using qRT-PCR. Numbers represent different lines. b Positive transgenic plants were verified using immunobloting with an anti-HA antibody. c Representative leaves with lesions resulted from inoculation with fungal discs of $A$. alternata $(0.5 \mathrm{~cm}$ in diameter). Photos were taken at 8 and $10 \mathrm{dpi}$. $\mathbf{d}$ Quantitation of the lesions was conducted by measuring lesion diameter. The data were analyzed for statistical differences by a two-way ANOVA followed by Tukey's posthoc test. Bars indicate the mean $\pm \mathrm{SD}(n=5)$. Asterisks indicate significant differences when compared to the WT $(* * 0<0.01)$

that chitin treatment enhances CERK1 expression and induces plant resistance to fungal and bacterial pathogens [1]. However, it has not yet been determined whether chitin-induced resistance correlates with the high levels of CERK1. If enhanced CERK1 expression is required for plant resistance, there are 2 possibilities regarding CERK1 function. One is that basal CERK1 levels are not enough for its PRR function, thereby enhanced CERK1 levels are necessary. The other is that CERK1 may play additional roles that differ from that as a PRR. In previous reports, transient CERK1 OE resulted in cell death in the absence of chitin or pathogen infection [38,
39], suggesting that CERK1 has a function that is independent of chitin signaling or pathogen infection. In this study, MdCERK1-2 OE improved $N b$ plant resistance to A. alternata, indicating that high MdCERK1-2 levels are important for its function.

Although MdCERK1-2 OE improved $\mathrm{Nb}$ plant resistance to fungal pathogens, no significant effects on the tested parameters were observed in the absence of chitin treatment or pathogen infection, including SA levels, phenol contents, gene expression, ROS accumulation, and callose deposition, suggesting that the function of MdCERK1-2 in plant immune responses depends on 


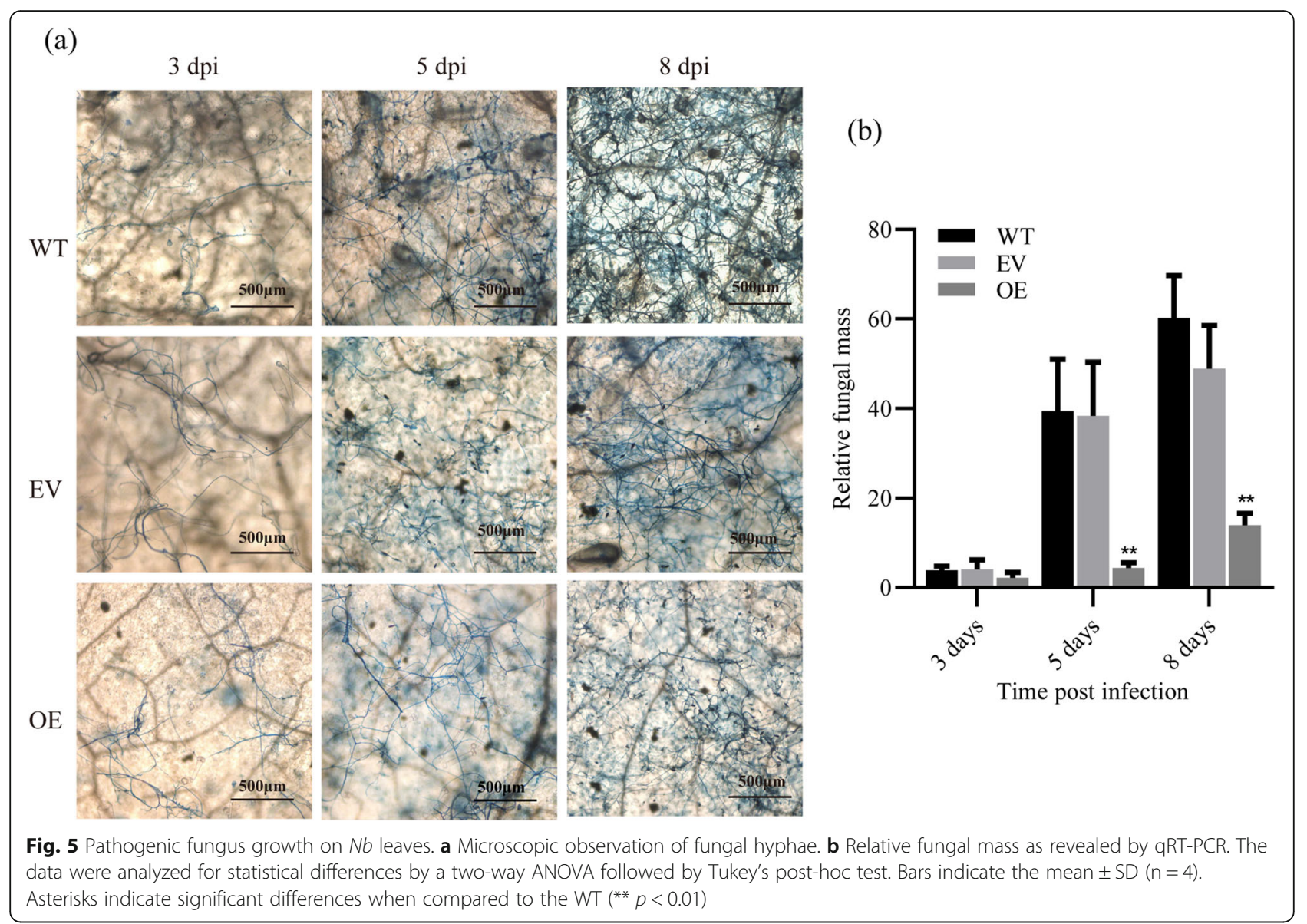

chitin signaling or pathogen infection. Notably, MdCERK1-2 OE resulted in increased ROS accumulation and callose deposition after $A$. alternata inoculation. This may represent a non-specific enhancement of defense responses mediated by $M d C E R K 1-2$ against microorganism invasion. ROS accumulation and callose deposition widely contribute to plant defense responses against fungal infections and are affected by LysM protein-medicated signaling $[9,38]$. Enhanced ROS accumulation and callose deposition in OE plants indicate that ROS accumulation contributed to the improved resistance of $\mathrm{Nb}$ plants to fungal pathogens.

MdCERK1-2 OE potentiated NbPAL4 expression in response to $A$. alternata infection. Other tested genes, including NbNPR1, NbPR1a, NbLOX1, and NbERF1, did not exhibit significant changes. These results suggest that the enhancement of resistance in OE plants to fungal pathogens compared to WT was related to polyphenolic metabolism, not to the SA, JA, or ethylene pathways. Several previous reports regarding LysMcontaining protein-mediated chitin signaling found that it was independent of the SA, JA, or ethylene signaling pathways, but it was related to phytoalexin [11, 19]. The data also showed significantly enhanced total phenolic contents in OE plants after $A$. alternata infection, which supports the influence of MdCERK1-2 on polyphenolic metabolism.

Previous studies found that CERK1 affects SA signaling pathways. Mutations in the ectodomain of CERK1 promote the accumulation of SA and enhances the resistance to biotrophic pathogens [40], while mutations in the kinase domain of CERK1 did not affect SA-induced defense responses [11]. SA regulates CERK1 levels and potentiates chitin-induced responses [41]. However, the results of this study found no significant differences in the SA levels between OE and WT plants after A. alternata infection, suggesting that the improvement of MdCERK1-2-mediated resistance did not result from the effects of $M d C E R K 1-2$ OE on SA levels.

\section{Conclusions}

An apple LyM-containing protein gene, MdCERK1-2, was identified in this study. MdCERK1-2 was involved in the anti-fungal defense responses of apple as a PRR. MdCERK1-2 OE improved the resistance of $\mathrm{Nb}$ plants to $A$. alternata infection. ROS accumulation, callose deposition, and polyphenols contributed to improved resistance. 


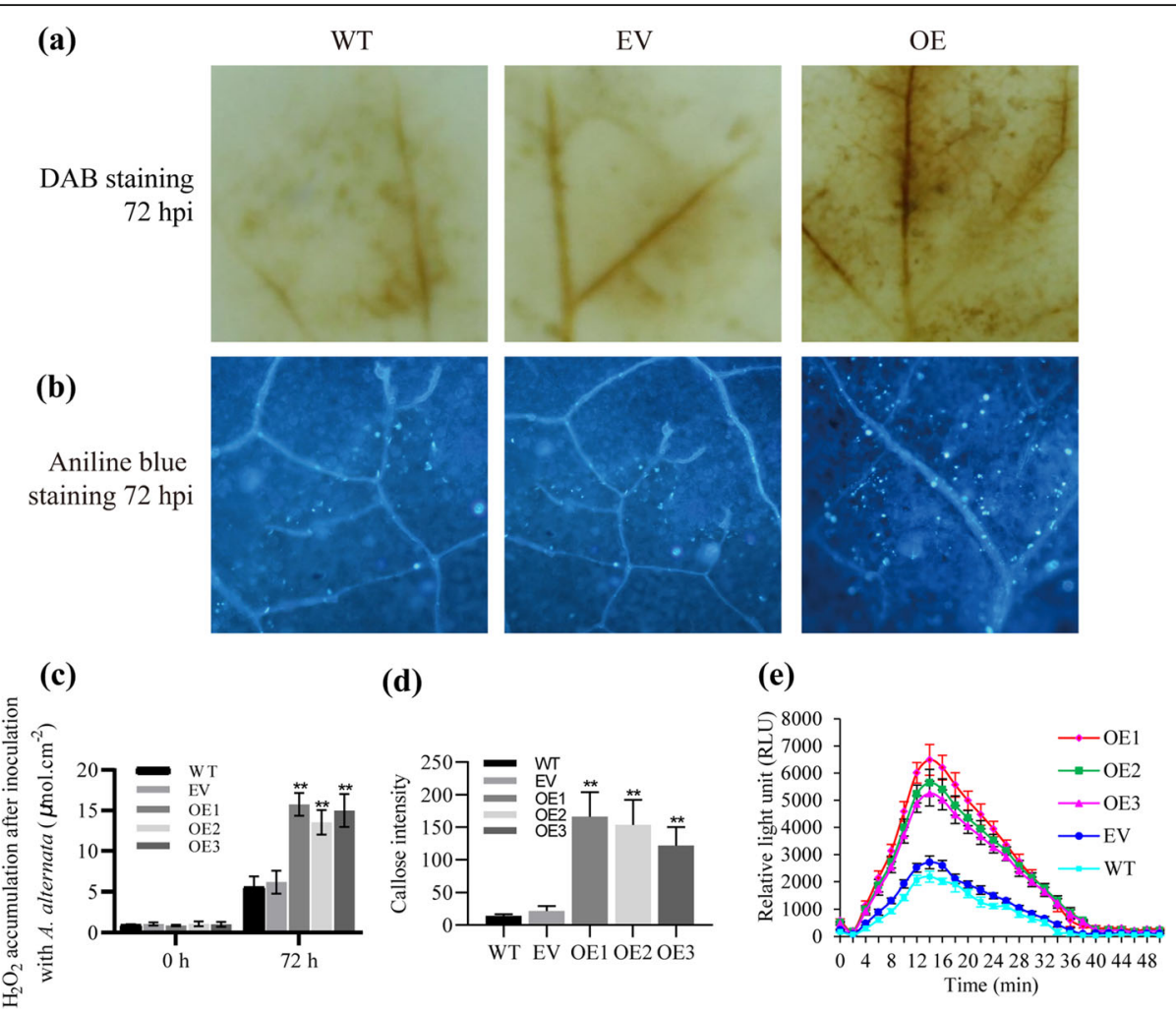

Fig. 6 ROS accumulation and callose deposition in Nb leaves responding to A. alternata infection. a ROS accumulation was visualized by DAB staining and (c) quantified by xylenol orange assay. b Callose deposition was visualized by aniline blue staining and (d) quantified by dot counting using Image J software based on 9 photographs. $\mathrm{H}_{2} \mathrm{O}_{2}$ generation in response to chitin treatment using luminol-based assays. The data were analyzed for statistical differences by a two-way ANOVA followed by Tukey's post-hoc test. Bars indicate the mean \pm SD of 5 independent biological replicates for $\mathrm{H}_{2} \mathrm{O}_{2}$ assays and 9 replicates for callose assays. Asterisks indicate significant differences when compared to the WT at the indicated time points $\left({ }^{* *} p<0.01\right)$

\section{Methods}

\section{Plant materials}

The 'Fuji' apple cultivar was obtained from the LAIXI breeding farm of the fruit nursery stock located in Qingdao, China, and confirmed by Hongyi Dai and Yugang Zhang. Two-yearold 'Fuji' apple trees were used for gene cloning and expression analysis. Trees were grown in a greenhouse under natural daylight conditions. $\mathrm{Nb}$ seeds were obtained from the Qingzhou Tobacco Research Institute of China National Tobacco Company, and were confirmed by Qiming Chen. Transgenic and WT $\mathrm{Nb}$ plants were cultured in a plant growth chamber under a 16/8-h light/dark photoperiod at $26^{\circ} \mathrm{C} / 22^{\circ} \mathrm{C}$.

\section{Pathogen inoculation}

For gene expression analysis in apple, current-year shoots were inoculated with $B$. dothidea as previously described [42]. Before inoculation, shoots were cleaned with $75 \%$ ethanol for surface sterilization. Mycelial strips were made from well-grown $B$. dothidea PDA plates with blades and wrapped onto the surface of shoots using polyethylene film. After 3 weeks, polyethylene film and mycelial strips were removed and the inoculated shoots were monitored for ring rot symptoms every 2 days. When visible warts had just formed, the barks of diseased shoots were collected and used for gene expression analysis. The same procedure was performed on other current-year shoots, except for substituting PDA for mycelial strips; these shoots were used as mock-inoculated controls.

For inoculation in $\mathrm{Nb}$ plants, the detached leaves from 7week-old plants were placed on $1 \%$ agar in petri dishes. Mycelial plugs ( $5 \mathrm{~mm}$ diameter) were made from PDA plates of actively growing A. alternata and cultured at $25^{\circ} \mathrm{C}$ for 1 week. Mycelial plugs were laid on detached $\mathrm{Nb}$ leaves for inoculation and kept at $25^{\circ} \mathrm{C}$. The fungal biomass in infected $N b$ leaves was determined at 3, 5 , and 8 dpi by qRTPCR using specific primers for the AaACTIN gene of $A$. alternata (Table S2), and normalized to the NbACTIN gene according to previously reported methods [43]. Trypan blue staining was used to detect mycelial growth and cell death according to previously described methods [44].

\section{Gene cloning and expression analysis}

To clone full-length coding regions (CDS) of MdCERK12 , primers were designed according to the sequences 


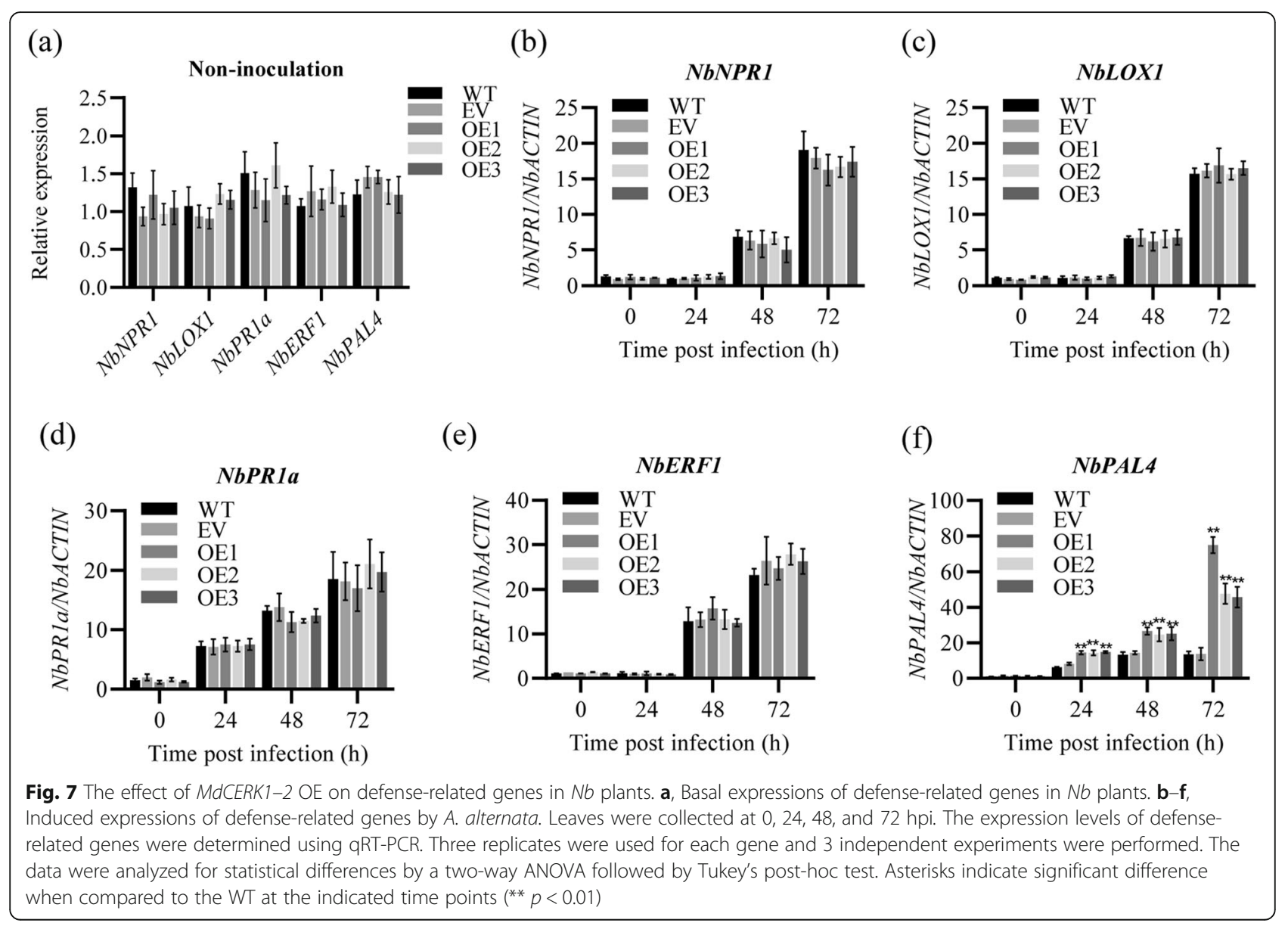

obtained from GDR and used for gene amplification. Total RNA were isolated using an EASYspin plant RNA rapid extraction kit (YP Biotech Co., Ltd., Beijing, China) and cDNA was synthetized using a PrimeScript ${ }^{\mathrm{tm}}$ II 1st strand cDNA synthesis kit (TaKaRa, Beijing, China) following the manufacturer's instructions. qRT-PCR was performed as previously described [42]. The primers used in the gene cloning and expression analysis are provided in Table S2.

\section{Subcellular localization}

Full-length CDS of MdCERK1-2 was integrated into pCAMBIA1300-221-GFP upstream of the GFP sequence to form a fusion protein with GFP. The resultant construct was transformed into A. tumefaciens EHA105. Transformed bacteria were cultured and resuspended in buffer (10 mM $\mathrm{MgCl}_{2}, 10 \mathrm{mM}$ 2-(N-morpholine)-ethanesulfonic acid (MES)-NaOH, pH 5.6, and $150 \mu \mathrm{M}$

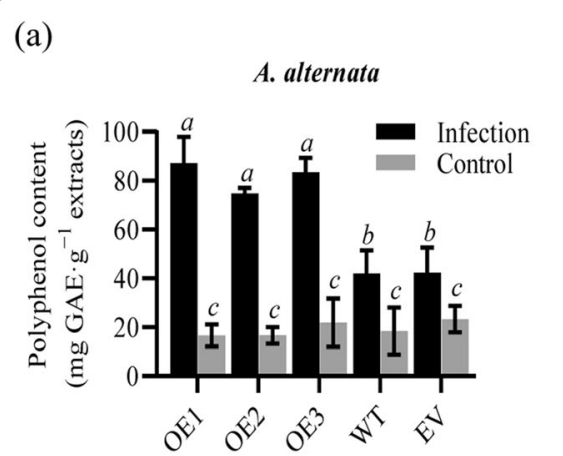

(b)

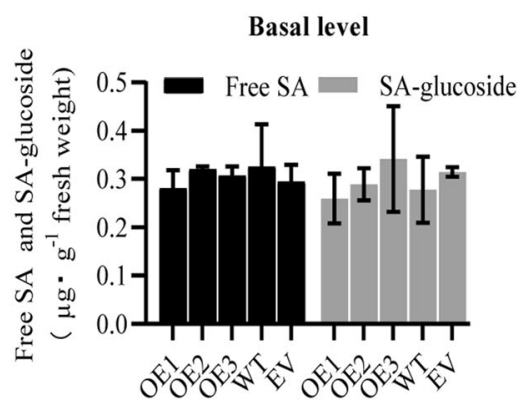

(c)

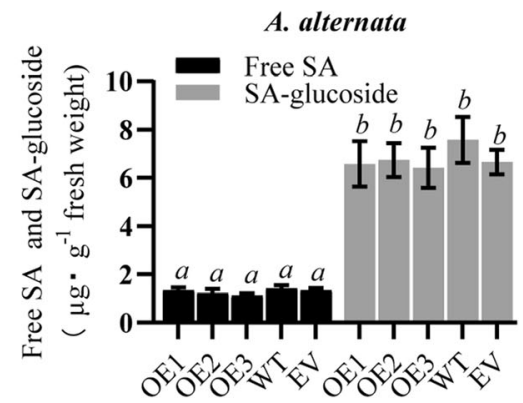

Fig. 8 The effect of MdCERK1-2 expression on polyphenol content and SA accumulation. a Polyphenol contents in OE, EV, and WT plants after A. alternata infection. b Basal SA levels in OE, EV, and WT plants. c SA levels in OE, EV, and WT plants after A. alternata infection. The data were analyzed for statistical differences by a two-way ANOVA followed by Tukey's post-hoc test. Bars represent the mean \pm SD $(n=4)$. Different letters indicate statistically significant differences; $p<0.05$ was regarded as being statistically significant 
acetosyringone) [38]. The bacterial concentration was adjusted to a final OD value of 0.5 at $600 \mathrm{~nm}$ and infiltrated into 4-week-old $\mathrm{Nb}$ leaves with a needleless syringe. Three days after infiltration, the infiltrated area was observed using a TCS SP5 confocal microscope (Leica Microsystems, Wetzlar, Germany) to localize MdCERK1-2-GFP fusion proteins. To verify the membrane localization of MdCERK1-2, microsomal and soluble proteins were prepared from $\mathrm{Nb}$ leaves transiently expressing MdCERK1-2-GFP following previously described methods [10]. The presence of MdCERK1-2GFP was determined by immunobloting with an antiGFP antibody (Abcam, Shanghai, China).

\section{In vitro chitin and PGN binding assays}

The MdCERK1-2 ectodomain was expressed and purified following previously described methods [45] with minor modifications. DNA fragments encoding the MdCERK1-2 ectodomain were amplified from cDNA of apple branch bark and inserted into pET-28a (+) between NcoI and XhoI. Recombinant DNA molecules were transformed into E. coli BL21 (DE3) for protein expression. Recombinant proteins were purified using a Ni-NTA column (GE Healthcare, Shanghai, China) under denatured conditions and refolded using the gradient dialysis method [45]. Protein concentrations were determined using the BCA method [46]. The same procedure was performed with AtLYM1-ECD, which were used as positive controls in the PGN binding experiment.

For in vitro chitin binding assays, the recombinant protein buffer was changed to binding buffer $(500 \mathrm{mM} \mathrm{NaCl}$, $20 \mathrm{mM}$ Tris- $\mathrm{HCl}, 1 \mathrm{mM}$ EDTA, and 0.05\% Triton X-100). The proteins were adjusted to a final concentration of 1.5 $\mathrm{mg} / \mathrm{mL}$. Chitin magnetic beads $(100 \mu \mathrm{L}$, NEB) were washed 3 times with $1 \mathrm{~mL}$ binding buffer and mixed with $50 \mu \mathrm{L}$ proteins (details outlined above) followed by incubation at $4{ }^{\circ} \mathrm{C}$ for $1 \mathrm{~h}$. After centrifugation, magnetic beads were washed 3 times with binding buffer. Then, beadbinding proteins were eluted by boiling in $50 \mu \mathrm{L}$ SDSPAGE loading buffer and detected by running $20 \mu \mathrm{L}$ on a $15 \%$ denaturing protein gel.

For the PGN binding assay, PGN $(50 \mu \mathrm{g})$ was mixed with purified proteins in $250 \mu \mathrm{L} 100 \mathrm{mM}$ PBS (pH 7.0) and incubated at $4{ }^{\circ} \mathrm{C}$ for $10 \mathrm{~min}$. After centrifugation at $12000 \times \mathrm{g}$ for $10 \mathrm{~min}$ at $4{ }^{\circ} \mathrm{C}$. The resultant pellet was washed 3 times with PBS ( $\mathrm{pH} 7.0$ ), dissolved in $100 \mu \mathrm{L}$ SDS sample buffer, and separated with SDS-PAGE followed by immunoblot with anti-His antibodies (Abcam, Shanghai, China).

\section{Genetic transformation of $\mathrm{Nb}$ plants}

The genetic transformation of $\mathrm{Nb}$ plants was performed using the A. tumefaciens-mediated leaf disc method [42]. The encoding cDNA of MdCERK1-2 was integrated downstream of the $35 \mathrm{~S}$ promoter of pCAMBIA1300221-HA. The resultant construct was transferred into the A. tumefaciens strain, EHA105, which was subsequently used for genetic transformation. The genetic transformation of $\mathrm{Nb}$ plants and verification of positive plants were conducted as previously described [42].

\section{Histochemistry and ROS measurements}

$\mathrm{H}_{2} \mathrm{O}_{2}$ accumulation and cell death were visualized by $\mathrm{DAB}$ and trypan blue staining, respectively, following previously described methods [47]. Briefly, leaves were incubated in a 3,3-diaminobenzidine (DAB) solution (1 $\mathrm{mg} / \mathrm{mL}$ ) overnight in the dark. Then, leaves were destained with a mixture of $80 \%$ ethanol and placed in a water bath at $65^{\circ} \mathrm{C} . \mathrm{H}_{2} \mathrm{O}_{2}$ quantitation was performed based on xylenol orange assays [47]. For measurements of $\mathrm{H}_{2} \mathrm{O}_{2}$ generation after treatment with chitin $(200 \mu \mathrm{g} /$ $\mathrm{mL}$ ), Luminol-based assays were performed according to previously described methods [48].

\section{Microscopic observation and quantification of callose deposition}

Callose deposition was examined according to previously described methods [49]. Briefly, $\mathrm{Nb}$ leaves inoculated with $A$. alternata were destained in a mixture of distilled water, glycerol, lactic acid, phenol saturated with water, and absolute ethanol at a ratio of 1:1:1:1:8 followed by staining with $0.01 \%$ aniline blue $(\mathrm{w} / \mathrm{v})$. Callose accumulation was examined using UV epifluoresence microscopy (350 nm/425 nm excitation/emission wavelengths, respectively) and quantified with digital photographs using Image J software. Callose measurements were determined based on 9 photographs and analyzed for statistical differences by a one-way ANOVA followed by Tukey's post-hoc test. A significance threshold of $p<$ 0.05 was used to determine significant differences.

\section{Measurement of total polyphenols and salicylic acid}

Total polyphenolic contents were measured according to previously described methods [50] with minor modifications. Fresh leaves $(4 \mathrm{~g})$ were collected and homogenized in $8 \mathrm{~mL}$ methanol. After centrifugation, the supernatant was used for total polyphenol measurements. Gallic acid was used as a standard reference and the values of polyphenols were expressed as gallic acid equivalents in per gram fresh weight of the leaves. SA levels were determined according previously described methods [42].

\section{Supplementary information}

Supplementary information accompanies this paper at https://doi.org/10. 1186/s12870-020-02361-z.

Additional file 1: Figute S1. CDS and amino sequences of MdCERK1-2 Bold letters with gray shadow indicate signal peptides. Letters in boxes 
indicate LysMs. Underlined letters indicate transmembrane regions. Letters with wavy lines indicate the catalytic domain of Ser/Thr protein kinases.

Additional file 2: Figure S2. Multiple sequence alignment among MdCERK1-2, AtCERK1, and OsCERK1 proteins. Identical amino acids are indicated with white letters and a black background. A gray background indicates high levels of similarity. Gaps are indicated by dashes to improve the alignment.

Additional file 3: Figure S3. The original blot presented in Fig. 2b (Top).

Additional file 4: Figure S4. The original blot presented in Fig. 2b (Middle).

Additional file 5: Figure S5. The original blot presented in Fig. 2c (Bottom). Additional file 6: Figure S6. The original blot presented in Fig. 2c (Top). Additional file 7: Figure S7. The original blot presented in Fig. 2c (Bottom). Additional file 8: Figure S8. The original blot presented in Fig. 4b (Top). Additional file 9: Figure 59. The original blot presented in Fig. $4 \mathrm{~b}$ (Bottom). Additional file 10: Table S1. The genes used in the present study. Additional file 11: Table S2. The primers used in this study.

\section{Abbreviations}

ABA: Abscisic acid; CEBiP: Chitin elicitor binding protein; CERK1: Chitin elicitor receptor kinase1; DAB: 3, 3-diaminobenzidine; EFR: Elongation factor-tu receptor; elf18: EF-Tu epitope; EV: Empty vector-transformed plants; flg22: Bacterial flagellin epitope; FLS2: Flagellin sensing 2; LYK: Lysin motifcontaining receptor-like kinase; LYM: LysM-containing glycosylphosphatidylinositol-anchored protein; LysM: Lysin motif; NAG: $\beta-1$, 4-linked N-acetyl-glucosamine; Nb: Nicotiana benthamiana; NF: Nodulation factor; OE: MdCERK1-2-overexpressing plants; PAMP: Pathogen-associated molecular pattern; PDA: Potato dextrose agar; PEPR: pep1 receptor; PGN: Peptidoglycan; PR: Pathogenesis-related protein; PRR: Pattern recognition receptor; PTI: PAMP-triggered immunity; Peps: Plant elicitor peptides; ROS: Reactive oxygen species; WT: Wild type plants

\section{Acknowledgments}

We would like to thank professor Baohua Li and associate professor Ruqin Zhang from Qingdao agricultural university for their kind help to provide us with pathogens. The authors are grateful to all the laboratory members for continuous technical advices and helpful discussions.

\section{Authors' contributions}

$\mathrm{SB}, \mathrm{CD}$ and $\mathrm{HD}$ conceived and designed the experiments. QC, CD and XS performed the experiments. QC, SB and YZ analyzed the data. SB and HD wrote the manuscript. All authors reviewed the final manuscript. The author(s) read and approved the final manuscript.

\section{Funding}

This research was supported by Agricultural Variety Improvement Project of Shandong Province (2019LZGC007), National Natural Science Foundation of China (No.31471853), China Agricultural Research System (No.CARS-27), Advanced Talents Foundation of Qingdao Agricultural University (No.631436), Qingdao Science and Technology Program (No. 12-1-4-5-(1)-jch) and The Project for Modern Fruit Tree Industry Techological System of Qingdao (6622316107). None of the funding bodies had any role in the design of the study and collection, analysis, and interpretation of data and in preparing the manuscript.

\section{Availability of data and materials}

The datasets used and/or analysed during the current study available from the corresponding author on reasonable request.

\section{Ethics approval and consent to participate}

All the plant materials used in the present study were grown and collected according to institutional and national guidelines. No field study was included in this study. Apple 'Fuji' used in this study is a common fruit-tree cultivar cultured worldwide and Nicotiana benthamiana is a widely used model plant species for research of plant-pathogen interactions. Both plant materials were originally obtained via a commercial approach and are not the Endangered Species of Wild Fauna and Flora, thus no voucher specimen of this material has been deposited in a publicly available herbarium.

\section{Consent for publication}

Not applicable.

\section{Competing interests}

The authors declare that they have no competing interests.

\section{Author details}

${ }^{1}$ College of Life Sciences, Key Laboratory of Plant Biotechnology of Shandong Province, Qingdao Agricultural University, 700 Changcheng Road, Qingdao 266109, China. ${ }^{2}$ Qingdao Key Laboratory of Genetic Improvement and Breeding in Horticultural Plants, Qingdao Agricultural University, Qingdao 266109, China. ${ }^{3}$ Shandong Province Key Laboratory of Applied Mycology, Qingdao 266109, China. ${ }^{4}$ College of Horticulture, Qingdao Agricultural University, Qingdao 266109, China.

Received: 1 August 2019 Accepted: 24 March 2020

Published online: 08 April 2020

\section{References}

1. Jones JD, Dangl JL. The plant immune system. Nature. 2006;444:323-9.

2. Tang D, Wang G, Zhou JM. Receptor kinases in plant-pathogen interactions: more than pattern recognition. Plant Cell. 2017;29:618-37.

3. Gomez-Gomez L, Boller T. FLS2: an LRR receptor-like kinase involved in the perception of the bacterial elicitor flagellin in Arabidopsis. Mol Cell. 2000;5: 1003-11.

4. Willmann R, Lajunen HM, Erbs G, Newman MA, Kolb D, Tsuda K, et al. Arabidopsis Lysin-motif proteins LYM1 LYM3 CERK1 mediate bacterial peptidoglycan sensing and immunity to bacterial infection. Proc Natl Acad Sci U S A. 2011;108:19824-9.

5. Zipfel C, Kunze G, Chinchilla D, Caniard A, Jones JD, Boller T, et al. Perception of the bacterial PAMP EF-Tu by the receptor EFR restricts Agrobacterium-mediated transformation. Cell. 2006;125:749-60.

6. Huffaker A, Ryan CA. Endogenous peptide defense signals in Arabidopsis differentially amplify signaling for the innate immune response. Proc Natl Acad Sci U S A. 2007;104:10732-6.

7. Krol E, Mentzel T, Chinchilla D, Boller T, Felix G, Kemmerling B, et al. Perception of the Arabidopsis danger signal peptide 1 involves the pattern recognition receptor AtPEPR1 and its close homologue AtPEPR2. J Biol Chem. 2010;285:13471-9.

8. Yamaguchi Y, Huffaker A, Bryan AC, Tax FE, Ryan CA. PEPR2 is a second receptor for the Pep1 and Pep2 peptides and contributes to defense responses in Arabidopsis. Plant Cell. 2010;22:508-22.

9. Miya A, Albert P, Shinya T, Desaki Y, Ichimura K, Shirasu K, et al. CERK1, a LysM receptor kinase, is essential for chitin elicitor signaling in Arabidopsis. Proc Natl Acad Sci U S A. 2007:104:19613-8.

10. Petutschnig EK, Jones AM, Serazetdinova L, Lipka U, Lipka V. The Lysin motif receptor-like kinase (LysM-RLK) CERK1 is a major chitin-binding protein in Arabidopsis thaliana and subject to chitin-induced phosphorylation. J Biol Chem. 2010;285:28902-11.

11. Wan J, Zhang XC, Neece D, Ramonell KM, Clough S, Kim SY, et al. A LysM receptor-like kinase plays a critical role in chitin signaling and fungal resistance in Arabidopsis. Plant Cell. 2008:20:471-81.

12. Shimizu T, Nakano T, Takamizawa D, Desaki Y, Ishii-Minami N, Nishizawa Y, et al. Two LysM receptor molecules, CEBiP and OsCERK1, cooperatively regulate chitin elicitor signaling in rice. Plant J. 2010;64:204-14.

13. Zhang XC, Cannon SB, Stacey G. Evolutionary genomics of LysM genes in land plants. BMC Evol Biol. 2009;9:183.

14. Liu T, Liu Z, Song C, Hu Y, Han Z, She J, et al. Chitin-induced dimerization activates a plant immune receptor. Science. 2012;336:1160-4.

15. Cao Y, Liang Y, Tanaka K, Nguyen CT, Jedrzejczak RP, Joachimiak A, et al. The kinase LYK5 is a major chitin receptor in Arabidopsis and forms a chitininduced complex with related kinase CERK1. Elife. 2014;3:e03766.

16. Kaku H, Nishizawa Y, Ishii-Minami N, Akimoto-Tomiyama C, Dohmae N, Takio K, et al. Plant cells recognize chitin fragments for defense signaling through a plasma membrane receptor. Proc Natl Acad Sci U S A. 2006;103: 11086-91.

17. Hayafune M, Berisio R, Marchetti R, Silipo A, Kayama M, Desaki Y, et al. Chitin-induced activation of immune signaling by the rice receptor CEBiP 
relies on a unique sandwich-type dimerization. Proc Natl Acad Sci U S A. 2014;111:E404-E13.

18. Zhang XC, Wu X, Findley S, Wan J, Libault M, Nguyen HT, et al. Molecular evolution of Lysin motif-type receptor-like kinases in plants. Plant Physiol. 2007;144:623-36.

19. Paparella C, Savatin DV, Marti L, De Lorenzo G, Ferrari S. The Arabidopsis LYSIN MOTIF-CONTAINING RECEPTOR-LIKE KINASE3 regulates the cross talk between immunity and abscisic acid responses. Plant Physiol. 2014;165:26276.

20. Wan J, Tanaka K, Zhang X-C, Son GH, Brechenmacher L, Nguyen THN, et al. LYK4, a Lysin motif receptor-like kinase, is important for chitin signaling and plant innate immunity in Arabidopsis. Plant Physiol. 2012;160:396-406.

21. Liao D, Cao Y, Sun X, Espinoza C, Nguyen CT, Liang Y, et al. Arabidopsis E3 ubiquitin ligase PLANT U-BOX 13 (PUB13) regulates chitin receptor LYSIN MOTIF RECEPTOR KINASE5 (LYK5) protein abundance. New Phytol. 2017;214: 1646-56.

22. Faulkner C, Petutschnig E, Benitez-Alfonso Y, Beck M, Robatzek S, Lipka V, et al. LYM2-dependent chitin perception limits molecular flux via plasmodesmata. Proc Natl Acad Sci U S A. 2013;110:9166-70.

23. Narusaka Y, Shinya T, Narusaka M, Motoyama N, Shimada H, Murakami K, et al. Presence of LYM2 dependent but CERK1 independent disease resistance in Arabidopsis. Plant Signal Behav. 2013;8:e25345.

24. Arrighi J-F, Barre A, Ben Amor B, Bersoult A, Soriano LC, Mirabella R, et al. The Medicago truncatula lysine motif-receptor-like kinase gene family includes NFP and new nodule-expressed genes. Plant Physiol. 2006;142:265-79.

25. Limpens E, Franken C, Smit P, Willemse J, Bisseling T, Geurts R. LysM domain receptor kinases regulating rhizobial nod factor-induced infection. Science. 2003;302:630-3.

26. Madsen EB, Madsen LH, Radutoiu S, Olbryt M, Rakwalska M, Szczyglowski K, et al. A receptor kinase gene of the LysM type is involved in legume perception of rhizobial signals. Nature. 2003:425:637.

27. Mulder L, Lefebvre B, Cullimore J, Imberty A. LysM domains of Medicago truncatula NFP protein involved in nod factor perception. Glycosylation state, molecular modeling and docking of chitooligosaccharides and nod factors. Glycobiol. 2006;16:801-9.

28. Radutoiu S, Madsen LH, Madsen EB, Jurkiewicz A, Fukai E, Quistgaard EM, et al. LysM domains mediate lipochitin-oligosaccharide recognition and $\mathrm{NFr}$ genes extend the symbiotic host range. EMBO J. 2007;26:3923-35.

29. Smit P, Limpens E, Geurts R, Fedorova E, Dolgikh E, Gough C, et al. Medicago LYK3, an entry receptor in rhizobial nodulation factor signaling. Plant Physiol. 2007;145:183-91.

30. Zhou Z, Tian Y, Cong P, Zhu Y. Functional characterization of an apple (Malus $x$ domestica) LysM domain receptor encoding gene for its role in defense response. Plant Sci. 2018;269:56-65.

31. Liu S, Wang J, Han Z, Gong X, Zhang H, Chai J. Molecular mechanism for fungal cell wall recognition by rice chitin receptor OsCEBiP. Structure. 2016; 24:1192-200.

32. Asai $\mathrm{S}$, Yoshioka $\mathrm{H}$. Nitric oxide as a partner of reactive oxygen species participates in disease resistance to nectrotophic pathogen Botryis cinerea in Nicotiana benthamiana. Mol Plant-Microbe Interact. 2009;22:619-29.

33. Zhai N, Jia H, Liu D, Liu S, Ma M, Guo X, et al. GhMAP3K65, a cotton Raf-like MAP $3 K$ gene, enhances susceptibility to pathogen infection and heat stress by negatively modulating growth and development in transgenic Nicotiana benthamiana. Int J Mol Sci. 2017;18:2462.

34. Brederode FT, Linthorst HJ, Bol JF. Differential induction of acquired resistance and PR gene expression in tobacco by virus infection, ethephon treatment, UV light and wounding. Plant Mol Biol. 1991;17:1117-25.

35. Jun S-Y, Sattler SA, Cortez GS, Vermerris W, Sattler SE, Kang C. Biochemical and structural analysis of substrate specificity of a phenylalanine ammonialyase. Plant Physiol. 2018;176:1452.

36. Shinya T, Motoyama N, Ikeda A, Wada M, Kamiya K, Hayafune M, et al. Functional characterization of CEBiP and CERK1 homologs in Arabidopsis and rice reveals the presence of different chitin receptor systems in plants. Plant Cell Physiol. 2012;53:1696-706.

37. Ao Y, Li Z, Feng D, Xiong F, Liu J, Li JF, et al. OsCERK1 and OsRLCK176 play important roles in peptidoglycan and chitin signaling in rice innate immunity. Plant J. 2014;80:1072-84

38. Yamaguchi K, Mezaki H, Fujiwara M, Hara Y, Kawasaki T. Arabidopsis ubiquitin ligase PUB12 interacts with and negatively regulates chitin elicitor receptor kinase 1 (CERK1). PLoS One. 2017;12:e0188886.
39. Pietraszewska-Bogiel A, Lefebvre B, Koini MA, Klaus-Heisen D, Takken FL, Geurts $R$, et al. Interaction of Medicago truncatula Lysin motif receptor-like kinases, NFP and LYK3, produced in Nicotiana benthamiana induces defence-like responses. PLoS One. 2013;8:e65055.

40. Petutschnig EK, Stolze M, Lipka U, Kopischke M, Horlacher J, Valerius O, et al. A novel Arabidopsis CHITIN ELICITOR RECEPTOR KINASE 1 (CERK1) mutant with enhanced pathogen-induced cell death and altered receptor processing. New Phytol. 2014;204:955-67.

41. Tateda C, Zhang Z, Shrestha J, Jelenska J, Chinchilla D, Greenberg JT. Salicylic acid regulates Arabidopsis microbial pattern receptor kinase levels and signaling. Plant Cell. 2014;26:4171-87.

42. Zhang W, Dong C, Zhang Y, Zhu J, Dai H, Bai S. An apple cyclic nucleotidegated ion channel gene highly responsive to Botryosphaeria dothidea infection enhances the susceptibility of Nicotiana benthamiana to bacterial and fungal pathogens. Plant Sci. 2018;269:94-105.

43. Qi M, Yang Y. Quantification of Magnaporthe grisea during infection of rice plants using real-time polymerase chain reaction and northern blot/ phosphoimaging analyses. Phytopathology. 2002;92(8):870-6.

44. Fernández-Bautista N, Domínguez-Núñez JA, Moreno MC, Berrocal-Lobo M. Plant tissue trypan blue staining during phytopathogen infection. Bio protoc. 2016;6:e2078.

45. Bai S, Dong C, Li B, Dai H. A PR-4 gene identified from Malus domestica is involved in the defense responses against Botryosphaeria dothidea. Plant Physiol Biochem. 2013;62:23-32.

46. Smith PK, Krohn RI, Hermanson GT, Mallia AK, Gartner FH, Provenzano MD, et al. Measurement of protein using bicinchoninic acid. Anal Biochem. 1985; 150:76-85.

47. Hwang IS, Hwang BK. The pepper mannose-binding lectin gene CaMBL1 is required to regulate cell death and defense responses to microbial pathogens. Plant Physiol. 2011;155(1):447-63.

48. Bisceglia NG, Gravino M, Savatin DV. Luminol-based assay for detection of immunity elicitor-induced hydrogen peroxide production in Arabidopsis thaliana leaves. Bio protoc. 2015;5(24):e1685.

49. Luna E, Pastor V, Robert J, Flors V, Mauch-Mani B, Ton J. Callose deposition: a multifaceted plant defense response. Mol Plant-Microbe Interact. 2011;24:183-93.

50. Gao H, Lu Z, Yang Y, Wang D, Yang T, Cao M, et al. Melatonin treatment reduces chilling injury in peach fruit through its regulation of membrane fatty acid contents and phenolic metabolism. Food Chem. 2018;245:659-66.

\section{Publisher's Note}

Springer Nature remains neutral with regard to jurisdictional claims in published maps and institutional affiliations.

\section{Ready to submit your research? Choose BMC and benefit from:}

- fast, convenient online submission

- thorough peer review by experienced researchers in your field

- rapid publication on acceptance

- support for research data, including large and complex data types

- gold Open Access which fosters wider collaboration and increased citations

- maximum visibility for your research: over $100 \mathrm{M}$ website views per year

At BMC, research is always in progress.

Learn more biomedcentral.com/submissions 